\title{
A Strategic Analysis of Cineworld
}

\author{
ZHAO Shuang \\ University of Kent, Canterbury, UK \\ Inner Mongolia University for the Nationalities, Tongliao, China
}

\begin{abstract}
Cineworld cinemas Ltd. is one of the leading cinema groups in UK with an annual revenue of $£ 348$ million. This project is to carry out a strategic analysis for Cineworld. It will apply SPENT analysis, Porter's Five Forces, and SWOT analysis to identify a strategic issue facing the Cineworld and then make appropriate recommendations on the future strategic plan of Cineworld Plc. The report will also present corporate social responsibility issues within Cineworld and show how the company responds them. The purpose of this report is to draw a strategic analysis of Cineworld and identify the strengths, weaknesses, opportunities, and threats of Cineworld. Product development is the final recommendation of this report to Cineworld cinemas Ltd.
\end{abstract}

Keywords: strategic analysis, internal analysis, external analysis

\section{Introduction}

This report will make a strategic analysis for Cineworld. It will start with introducing the Cineworld group. The project will then make an external analysis of the cinema industry in the UK in order to identify the major environmental influencing factors and competitive forces. Following on from this, the project will then make an internal analysis which identifies the strengths and weaknesses of Cineworld. The project will also present corporate social responsibility issues within Cineworld and how the company responds them. Finally, the project will provide recommendations and an overall conclusion.

The aim of this report is to carry out a strategic analysis of Cineworld Plc. and identify the strengths, weaknesses, opportunities, and threats to identify a strategic issue facing the company then make appropriate recommendations on the future strategic plan of Cineworld Plc.

\section{Background}

Cineworld cinemas Ltd. was set up in 1995 by Steve Wiener. The company currently owns 80 cinemas with an annual revenue of $£ 348$ million and has become one of the leading cinema groups in UK. In the past 8 years, Cineworld group has acquired UGC cinemas, the O2 Cinema at Greenwich, and the Picturehouse chain of cinemas. Cineworld was listed on the London Stock Exchange as of May 2007. Cineworld group is the only one cinema company in the UK that adopts the subscription business model using the unlimited membership card. The unlimited membership card allows subscribers free entrance with a set amount of money per month and provides nine discounts for all drink and food. The vision of Cineworld is to provide a welcoming environment and contemporary cinemas that create a smooth, exciting, and memorable experience and make

ZHAO Shuang, master, Business School, University of Kent; School of Economics and Management, Inner Mongolia University for the Nationalities. 
the audience visit time and time again. The mission of Cineworld is to reinforce and advance its current position as one of the leading cinema groups in the UK through providing a wide range of movies and high quality of customer service (Cineworld, 2011).

\section{Strategic Analysis}

\section{External Analysis}

Campbell, Edgar, and Stonehouse (2011) argued that it is important to scan and monitor the macro-environment (SPENT) for potential changes and assess the impact of these changes on the market and industry. Porter's Five Forces enable an industry analysis to be carried out for developing competitive strategy.

SPENT analysis. Sociodemographic. According to research carried out by the UK Film Council (2010), the most frequent cinema visitors in 2009 were teenagers and young adults aged 15-24, followed by adults aged 45 and above whose number increased dramatically from $14 \%$ in 1997 to $30 \%$ in 2008, while the number of adults aged 25-34 decreased significantly from 29\% to 18\% (see Appendix A). Moreover, the research by YouGov (2010) showed that $61 \%$ of viewers visit the cinema because of the big screen and unique social experience.

Political. In terms of the political environment, Cineworld works closely with UK government, as company's business can be influenced by the local regulations, which include the matters of planning, environment, health, safety, and licensing (Cineworld, 2011). If Cineworld does not follow these legislations, it will be subject to fines. Moreover, any changes in regulation will require additional cost for the company. Most recently the government's decisions over budget cuts will impact on public sector funding into the film industry, the UK film industry relies heavily on independent filmmakers to enable the continued development of UK production into UK cinemas (Grove, 2012).

Economic. In 2011, it was estimated that the UK film industry helped contribute $£ 4.6$ billion to UK GDP ("UK film industry," 2012). In 2012, UK cinema admissions stood at 172.5 million, the second highest on record in the last 10 years. Research carried out for this report has suggested that despite economic conditions the UK film industry shows continuing growth. Cineworld may however still have to face challenges with the continuing economic downturn, increased competition, and a predicted further rise in inflation from $2.7 \%$ to $3 \%$ by Summer 2013 ("Inflation to stay above target," 2013). The continuing recessionary impact on consumer spending may result in a reduction in demand for cinema admissions which could have a negative impact on the financial situation of Cineworld.

Technological. Technology is a crucial factor in the cinema industry and one that enables Cineworld to remain competitive. Most recently cinemas have had to embrace the digital switchover and the introduction of 3D cinemas which has helped see the rise in cinema revenues. The online distribution of films is becoming more common. The introduction of new technologies, like 3D television and online movies, which offer consumers ease of access, convenience, and at potentially competitive prices may affect cinema goer's attitude towards Cineworld.

Porter's Five Forces. Industry competitors. The three market leaders in the UK cinema industry are Odeon, Cineworld, and Vue. According to a mintel report (2011), Cineworld gained position as market leader with a 26.2\% market share, whilst in terms of share of venues and screens Cineworld sits second just behind Odeon (see Appendix B). In addition, 3D television, online movies, and online downloading are the indirect competitors of Cineworld which have the potential to negatively impact Cineworlds competitive advantage. 
Potential entrants. Cineworld (2011) identify that there are significant barriers to entry. Entering this market would involve in credibly high start up costs and access to capital in the current economic climate proves incredibly difficult. Access to land and property to develop venues has also become more difficult and there has been a decline in the number of new cinema openings (Cineworld, 2011).

Substitutes. There are a couple of very strong substitutes in the form of Odeon and Vue cinemas. The survey by YouGov (2010) showed that $50 \%$ of the people in the UK found that going to the cinema has become too expensive. Thus, there is a possibility of switching to the substitutes, such as movie channels on television or online movies.

Bargaining power of suppliers. Cineworld works closely with its suppliers. Their relationship with the film distributors is most complex, due to the negotiable nature of this relationship, which works on a film by film basis, with each party receiving a certain percentage of the box office revenue (Cineworld, 2013). The bargaining power here generally depends on the size of the distributor, if the distributor is fairly small Cineworld will have the greater power, where as with the larger distributors negotiation will involve a number of factors. As known, if there is no substitute to the supplier or the supplier has many clients, he has more bargaining power. According to Cineworld (2011), the loss of the suppliers may cause temporary disruption for Cineworld.

Bargaining power of buyers. In view of these facts, one can conclude that as there are substitutes available and more customers consider cinema's prices to be expensive, customers have greater bargaining power, as they might switch to other alternatives.

\section{Internal Analysis}

Analyzing the internal components of Cineworld can enable us to determine its strengths and weaknesses; we can also see its current resources, how they are managed and where their competitive advantage lies.

Resource audit (see Appendix C). Human. Cineworld has two main sectors of staff that have been identified. Those at the functional level working in the cinemas, who have direct interaction with the consumers and provide the customer service. Then there are the directors and managers at Head office providing direction and strategy for the whole company and co-ordinating all 80 cinemas. At both these levels there is a large resource of skills, with employees from various backgrounds with different levels of experience. Cineworld put a strong emphasis on the recruitment process as well as professional development, with training programmes implemented to support this.

Physical. Cineworld currently has a portfolio of 80 sites, 77 of which are multiplex cinemas (those with five or more screens). Cineworld has embraced both the digital switchover and the introduction of 3D films, aiming to remain at the forefront of technological advancements to offer an enhanced service in comparison to the competition. Cineworld are using their competitive position to continue expanding, with new cinema openings planned throughout 2012 and 2013. To enhance capacity utilization Cineworld have also made screening rooms available for hire for private functions as well as a partnership with De Vere Venues making venues available for hire to business.

Financial. In 2011, Cineworld opened a new $£ 70$ million term loan and a credit facility of $£ 100$ million to finance further expansion. Cineworld have reported strong financial performance with a $4.8 \%$ rise in dividend payments in 2011. Cineworld have created new opportunities of creating income through hiring out screening rooms for private functions as well as their screen advertising company Digital Cinema Media, a joint venture with Odeon UCI Cinemas (Cineworld, 2011). 
Intangible resources. Cineworld have invested heavily in the technological side of their business which helps them remain competitive. With improved smart phone App and websites that assist consumers choice films, Cineworld maintains a consistent relationship with its suppliers to avoid disruption to its service. The MyCineworld membership database also provides Cineworld with invaluable data on consumer patterns. They are also the only cinema to offer a subscription service, with 280,000 members encouraging customer loyalty (Cineworld, 2011).

Corporate social responsibility. Cineworld have made a conscious effort to reduce their carbon footprint and introduced new energy saving measures at many of their sites. The digital switchover has reduced use of raw materials in the production of film reels which could also not be recycled once they were finished with. Cineworld now recycles and charges a small fee for 3D glasses to encourage customers to reuse their glasses.

Value chain analysis. In order to analyze Cineworlds' competitive advantage, the report will look at the company's value chain analysis. This report applied the framework which suggested by Porter in 1985 . This framework can help companies understand their sources of value and check their activities (Campbell, Edgar, \& Stonehouse, 2011). The value chain analysis in relation to Cineworld has highlighted the importance of customer service in adding value to Cineworld's operations. As well as being innovative in the ways they offer their service and investing heavily to remain up to date with new technology such as 3D screenings and the digital switchover.

Primary activities. Inbound logistics. This would be the receipt of film from the distribution companies as well as food and drink from its suppliers for its customers. Cineworld has to have the most up to date films and releases to ensure it can compete with other cinemas.

Operations. Cineworld is essentially a service, and operations would consist of tasks such as providing a good customer service as well as ensuring customers a pre-booking advantage, making sure that movies are not over booked.

Sales and marketing. (1) Providing discounts for certain age groups to the cinema, (2) consistently having trailers for upcoming films playing before the main feature, and (3) keeping prices low to rival competitors such as the Odeon.

Service. (1) Providing a quality service to customers as well as dealing with complaints and (2) keeping all film screenings on time and not overbooking the cinema.

Support activities. Procurement. Purchasing those movies that are likely to rival competitors, but as well as purchasing the rights to movies that target a niche market.

Technology development. Using up to date screening and sound systems to ensure the best quality for their customers.

Strategic problem identified for Cineworld. Technological advancements: Subsitute products identified in Porter's Five Forces framework—online distribution and downloading.

SWOT Analysis

\begin{tabular}{|l|l|}
\hline Strengths & Weaknesses \\
\hline (1) Strong portfolio and infrastructure & (1) Limited focus on CSR initiatives \\
(2) Acquisition of smaller competitors & (2) Strong focus on customer service at management/strategic level, \\
(3) Cheaper ticket prices in comparison to their competitor & which is not always reflected at the functional level \\
Odeon & \\
(4) Investment in new equipment and technology & \\
(5) MyCineworld subscription database & \\
\hline
\end{tabular}




\begin{tabular}{|l|l|}
\hline Opportunities & Threats \\
\hline (1) Growing popularity of cinema among elderly generation & (1) Economic recession-less disposable income \\
(2) The developing use of online film distribution and downloads & (2) Increase in online downloading \\
& (3) Piracy and illegal downloads \\
& (4) A few strong substitutes, high potential for customers to \\
switch to substitute products and services
\end{tabular}

\section{Recommendations}

It is the recommendation of this report that Cineworld look at expanding into the online market. The most suitable strategy to solve the issues that Cineworld faces currently is product development. This can be achieved through entering the online market to take advantage of developments in online movie distribution and not lose market share to indirect competitors such as Netflix and LoveFilm. This strategic option would help Cineworld increase the market for its services and improve customer relations as they would be able to gain consumer data to help them personalize their services, creating core competences and competitive advantage. This option also indirectly has the ability to help Cineworld continue to fight against illegal downloading. It will also help them to differentiate themselves from the competitors and reach more customers around the world. This strategy recommends that Cineworld enters online streaming through the acquisition of an internet television network. It will also enable Cineworld to reach audiences on a global scale. However, the company will face several implementation issues, such as different organizational culture and structure of the acquired company that will require new management and leadership style.

\section{Conclusion}

In conclusion, the resources identified throughout this report have enabled Cineworld to be one of the leading cinemas in the UK. The internal analysis has shown that Cineworld holds a large quantity of resources both tangible and intangible, which help it appeal to a mass market as well as being able to target niche markets. Its pool of resources also helps the company differentiate itself from competitors and help it react to changes in the external environment. It has a strong portfolio of venues around the country and the financial capabilities to contend with larger cinemas such as the Odeon.

The results from this paper indicate that one of the major strategic issues that Cineworld faces is the development of online streaming and downloading of movies. Moreover, another issue that Cineworld faces is the high competition in the Cinema industry and issue of illegal downloads.

\section{References}

Bainbridge, J. (2012). Cinemas. Marketing (00253650), 19, 23.

Campbell, D., Edgar, D., \& Stonehouse, G. (2011). Business strategy: An introduction (3rd ed.). London: Palgrave Macmillan. Cineworld. (2011). Cineworld Group Plc. Annual report 2011. Retrieved from http://www.cineworldplc.com/download/pdf/ Annual_Report_2011.pdf

Cineworld. (2013). The market: UK and Ireland market overview. Retrieved from http://www.cineworldplc.com/market

Goodman, A. (2011). Movie search and display trends [Microsoft Advertising Online]. Retrieved from advertising.microsoft.com

Grove, E. (2012). 7 challenges facing independent filmakers. Retrieved from http://www.raindance.org/7-challenges-facingindependent-filmmakers

Inflation to stay above target. (2013). BBC News. Retrieved from http://www.bbc.co.uk/news/business-21440080

Mintel Report. (2011). Leisure venue catering-UK (pp. 105-120). Retrieved from http://store.mintel.com/leisure-review-ukdecember-2012 
UK Film Council. (2010). 2010 statistical yearbook. Retrieved from http://industry.bfi.org.uk/media/pdf/e/q/Statistical_ Yearbook_2010.pdf

UK film industry worth £4.6bn in 2011. (2012). BBC News. Retrieved from http://www.bbc.co.uk/news/entertainment-arts $-19623067$

YouGov. (2010). Cinema going habit. Retrieved from http://yougov.co.uk/publicopinion/archive/3136/

Appendix A: Annual Cinema Admission: By Age

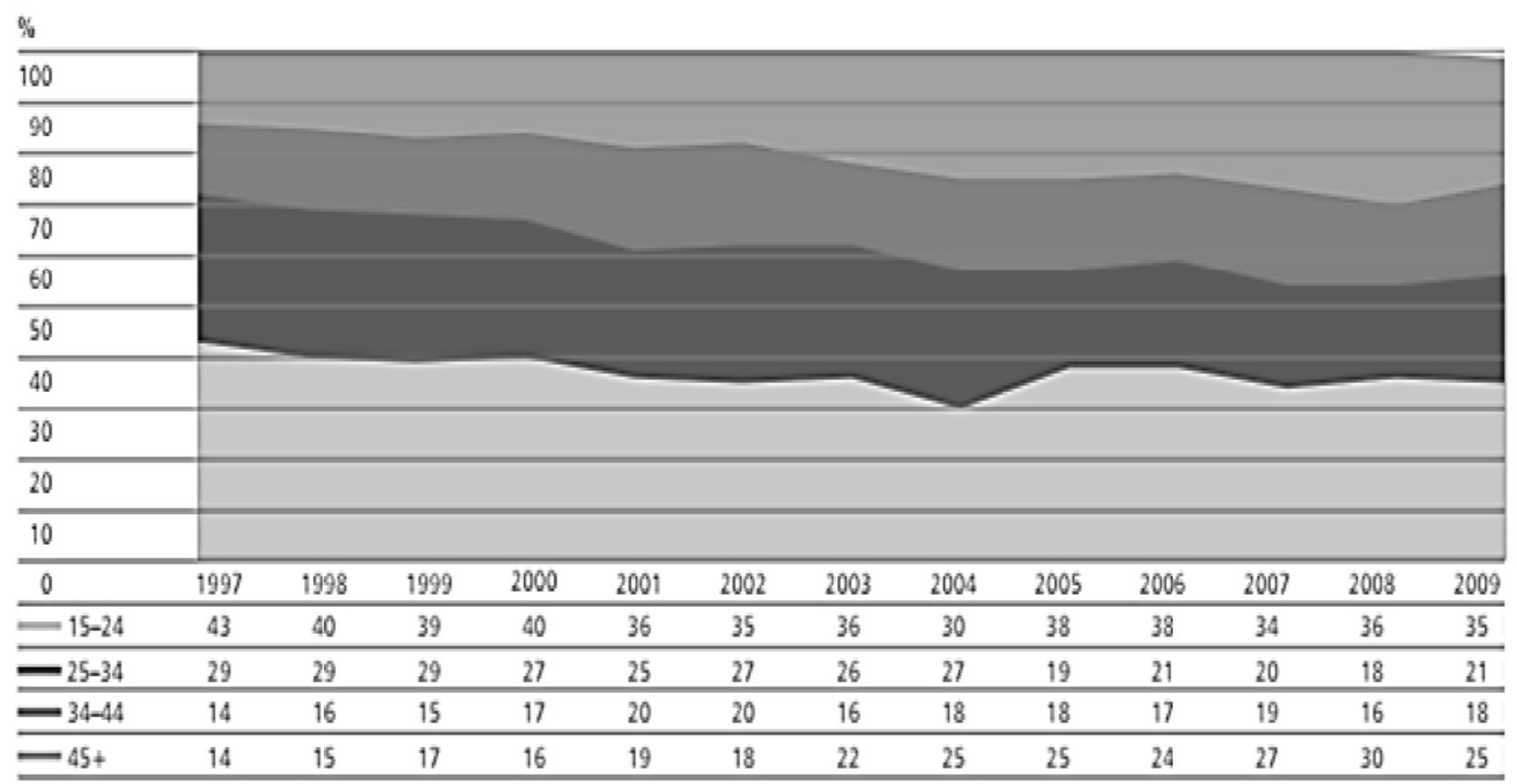

Note. Adapted from UK Film Council, 2010.

Appendix B: Cinema Market Shares

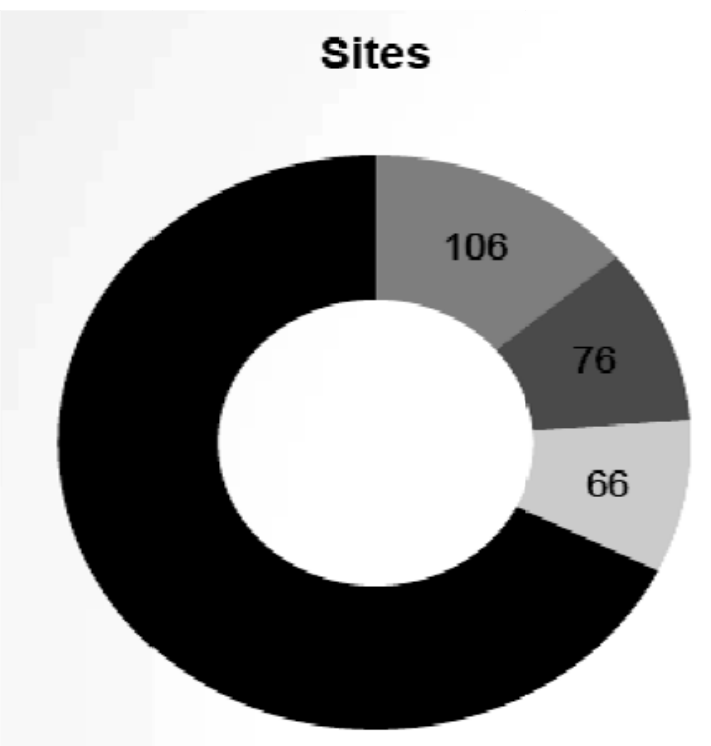

- Odeon Cineworld vue a Others
Screens

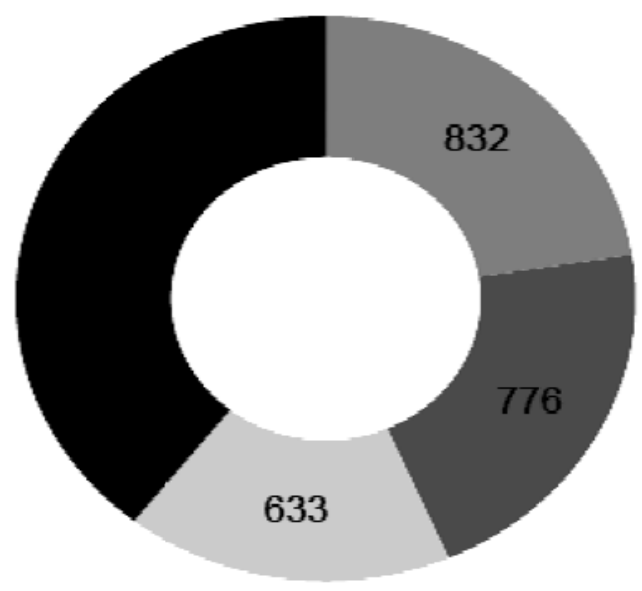

adeon $\square$ Cineworld vue $\square$ Others

Note. Adapted from Goodman, 2011 (Microsoft Advertising). 


\section{Appendix C: Resource Audit}

\begin{tabular}{|c|c|}
\hline \multicolumn{2}{|l|}{$\begin{array}{l}\text { Tangible Resources } \\
\text { Human Resource Audit }\end{array}$} \\
\hline Job roles & $\begin{array}{l}\text { (1) Four main functional roles that are essential to service delivery: team members, } \\
\text { supervisors, operations managers, and general managers. } \\
\text { (2) The key focus within these roles is on delivering customer service. } \\
\text { (3) The board of directors provides strategic direction which is then passed down to } \\
\text { managers at the functionallevel. }\end{array}$ \\
\hline Diversity & $\begin{array}{l}\text { (1) Equal opportunties employer recruiting a wide and diverse workforce. } \\
\text { (2) A wide variety of ages are evidenced at Cineworld large proportion of students in } \\
\text { functional roles, in the Cineworld annual report a wide variety of ages are evidenced at } \\
\text { manager and director level (2011). } \\
\text { (3) Gender diversity is more balanced at the functional level and becomes more male } \\
\text { dominated further up the organizational hierarchy (Appendix C). }\end{array}$ \\
\hline Skills & Functional level staff: team work, customer service skills. \\
\hline Training & $\begin{array}{l}\text { (1) The academy for high potential cinema managers. } \\
\text { (2) The step up programme for multifunctional staff. }\end{array}$ \\
\hline Motivation & $\begin{array}{l}\text { (1) Cineworld have stated their focus is to "ensure staff are engaged, motivated and } \\
\text { retained”. } \\
\text { (2) Motivated is important to provide a high level of service. }\end{array}$ \\
\hline Attitudes and cultural awareness & $\begin{array}{l}\text { (1) Importance of local community and societal issues as well as a focus on diversity. } \\
\text { (2) In } 2011 \text { Cineworld were the number one exhibitor of Bollywood films in the UK. } \\
\text { (3) Non-Enligsh languagetitles. } \\
\text { (4) Independent productions. } \\
\text { (5) Introduction of polish releases. }\end{array}$ \\
\hline Remuneration & $\begin{array}{l}\text { (1) Bonuses have been distributed } 17 \text { years consecutively. } \\
\text { (2) A share options scheme is available for all staff. }\end{array}$ \\
\hline
\end{tabular}

\begin{tabular}{|l|l|}
\hline Physical Resources & $\begin{array}{l}\text { (1) Cineworld state they offer: “Clean, comfortable, well-runfacilities in well-sited } \\
\text { locations”. } \\
\text { (2) Cinema venues are mostly located in town and city centres and retail parks. }\end{array}$ \\
\hline Expansion & $\begin{array}{l}\text { (1) Cineworld are continuing to expand with a number of new openings throughout } \\
\text { 2011 \& } 2012 \text { A new concept cinema in Cheltenham. } \\
\text { (2) A seven screen cinema in Leigh. } \\
\text { (3) A seven screen cinema in Aldershot. } \\
\text { (4) Opening of first IMAX screen at Edinburgh cinema. }\end{array}$ \\
\hline Capacity utilisation & $\begin{array}{l}\text { (1) Venue hire. } \\
\text { (2) Development of partnership with De Vere Venues which opens up venues for } \\
\text { business use, this is currently being trialled in three London venues. } \\
\text { (3) Digital Cinema Media is Cineworlds screen advertising business a joint venture with } \\
\text { Odeon UCI. }\end{array}$ \\
\hline Land & $\begin{array}{l}\text { Cineworld maintain relationships with developers to enable access to the best sites } \\
\text { (Cineworld, 2011). }\end{array}$ \\
\hline Computer and communication & $\begin{array}{l}\text { (1) Groups IT Systems } \\
\text { (2) Ticketing System } \\
\text { (3) Screens \& Projectors }\end{array}$ \\
\hline
\end{tabular}




\begin{tabular}{|c|c|}
\hline \multicolumn{2}{|l|}{ Financial Resources } \\
\hline $\begin{array}{l}\text { Global sources and availability of } \\
\text { finance: }\end{array}$ & \\
\hline Borrowing capacity & $\begin{array}{l}\text { A £70m term loan with repayments of } £ 2.5 \mathrm{~m} \text { every six months commencing June } 2011 \\
\text { and a revolving credit facility of } £ 100 \mathrm{~m} \text {. }\end{array}$ \\
\hline Internal fund generation & $\begin{array}{l}\text { Venue Hire } \\
\text { Digital Cinema Media—Cinema advertising } \\
\text { Share Capital }\end{array}$ \\
\hline Global assets and liabilities & $\begin{array}{l}\text { Assets: property and computer systems } \\
\text { Liabilities: staff salaries, property rent \& rates, energy, repairs and maintenance costs, } \\
\text { film rental, food \& drink supply. }\end{array}$ \\
\hline Taxation & In 2011 taxation charge of $£ 9.5 \mathrm{~m}$ with corporation tax of $£ 8.5 \mathrm{~m}$ \\
\hline
\end{tabular}

\begin{tabular}{|c|c|}
\hline \multicolumn{2}{|l|}{ Intangible Resources } \\
\hline Technology \& IT resources & $\begin{array}{l}\text { (1) Major IT systems upgrade } \\
\text { (2) Digital conversion } \\
\text { (3) Use of technology for integrated marketing, booking, and ticketing. } \\
\text { (4) Internet \& Mobile devices including applications for bothiphone \& android } \\
\text { (5) MyCineworld membership with a database of over 900,000 members. }\end{array}$ \\
\hline Patents \& Copyrights & Requires legal permission to exhibit films. \\
\hline $\begin{array}{l}\text { IT and communication systems (internal } \\
\text { and external) }\end{array}$ & $\begin{array}{l}\text { (1) IT used for ticket booking } \\
\text { (2) Digital conversion-all films transferred straight from distributor to cinema hard } \\
\text { drive } \\
\text { (3) Finance systems }\end{array}$ \\
\hline $\begin{array}{l}\text { Customer, supplier and competitor } \\
\text { information }\end{array}$ & $\begin{array}{l}\text { (1) Production companies use distributors to publicise films \& gain cinemaspace before } \\
\text { release to dvd \& other distribution channels. } \\
\text { (2) Two direct competitors Odeon \& Vue } \\
\text { (3) The rest of the market is made up of smaller multiplex cinemas and independents }\end{array}$ \\
\hline $\begin{array}{l}\text { Relationships with suppliers, } \\
\text { distributors and customers }\end{array}$ & $\begin{array}{l}\text { (1) Maintenance and development of relationships with distributors, film studios (major } \\
\text { \& independent) } \\
\text { (2) Market knowledge \& understanding of changing consumer needs. Development of } \\
\text { subscription programme. }\end{array}$ \\
\hline Customer loyalty & Fixedmonthly/annualsubscription service-unlimited 280,000 members. \\
\hline Price premium & $\begin{array}{l}\text { The price of going to the cinema in comparison to other activities make it remain a key } \\
\text { activity. }\end{array}$ \\
\hline Organization reputation & $\begin{array}{l}\text { (1) Focus on customer experience } \\
\text { (2) Staff development } \\
\text { (3) CSR \& ethical policies in place } \\
\text { (4) Key relationship maintenance } \\
\text { (5) Risk management }\end{array}$ \\
\hline CSR & $\begin{array}{l}\text { (1) Carbon footprint reduction } \\
\text { (2) Recycling 3D glasses } \\
\text { (3) Reduction in no. of deliveries from suppliers }\end{array}$ \\
\hline
\end{tabular}

